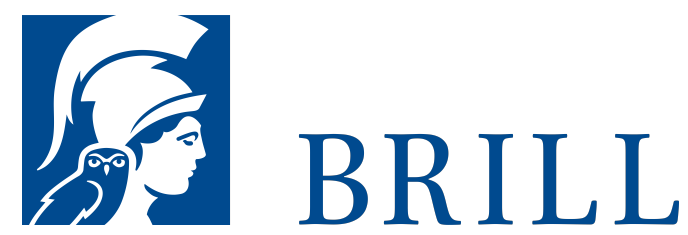

\title{
The Foundations of Jurisprudence - An Introduction to Imāmī Shīì Legal Theory
}

\section{Author: al-'Allāmah al-Ḥillī}

\section{Foundations ofJurisprudence: An Introduction to Imāmī Shī‘}

Legal Theory is a critical edition of the Arabic text with a parallel English translation of Mabādi' al-wușūl ilā 'ilm al-uṣūl by al-'Allāmah al-Ḥillī, introduced, edited and translated by Sayyid Amjad H. Shah Naqavi.

Al-'Allāmah al-Ḥillī participated in the leading debates of his day and applied his vast erudition in philosophy, logic, and theology to the paramount subject of jurisprudence. This text presents an exemplar of the rich revival of Shīis scholarship in the thirteenth and fourteenth centuries of the Common Era. Concise, yet comprehensive, this work sets the standard for the subsequent development and discussion of Imāmī Shīì legal theory, such that its influence can be traced through to modern times. This dual-text edition is indispensable for students and scholars of Imāmi Shīī jurisprudence.

Readership

Students and scholars seeking a broad understanding of the origins, principles, and intellectual development of jurisprudence (ușul al-fiqh) regarding Islamic revealed law (sharīah), particularly from an Imāmīyyah Shīah perspective.

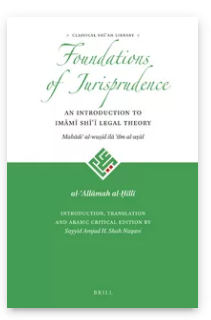

Pages: xviii, 274

$\mathrm{pp}$

Language:

English

Subjects:

Islamic Law,

Middle East and

Islamic Studies,

Laws of the

Middle East,

International

Law, Legal

Philosophy,

Philosophy,

Afro-Asiatic

Languages,

Languages and

Linguistics,

Legal History,

History

Publisher: Brill

Series:

The Classical

Shī‘ah Library,

Volume: 1

E-Book (PDF)

Released online:

o7 Nov 2016

ISBN: 978-9o-

04-31177-O

List price

USD \$99.00

Hardback 
Jamāl al-Dīn Abū Manșūr al-Ḥasan b. Sadīd al-Dīn Yūsuf b.

ISBN: $978-90-$ Zayn al-Dīn 'Alī b. al-Muṭahhar al-Ḥillì (d. 726 AH/1325 CE) was an influential and prolific scholar, jurist, and theologian of the Imāmī Shīì school of Hillah, whose unrivalled mastery of the Islamic sciences earned him the unique title of al-'Allāmah, or 'Doctor Maximus'.

Sayyid Amjad H. Shah Naqavi holds a PhD from the University of Edinburgh. He is the Dean of the Shīah Institute in London, the translator of The Mystery of Prayer (Brill, 2015), and is currently working on an English translation of the Nahj albalāgah.

04-31171-8

List price

USD \$99.00

Paperback

Publication date: 10 Nov 2016

ISBN: $978-90-$

04-31173-2

List price

USD $\$ 65.00$

For more information see brill.com

Order information: Order online at brill.com +44330 3330049 | customerservices@brill.com Submission information: brill.com/authors

Titles published by Brill | Fink, Brill | mentis or Brill | Schöningh: +49(o)71 5413279216 | brill@brocom.de 